\title{
Research on Horizontal Coefficient of Consolidation of Vietnam's Soft Soil
}

\author{
Nu Nguyen Thi ${ }^{D},{ }^{1}$ Bui Truong Son, ${ }^{1}$ and Do Minh Ngoc $^{2}$ \\ ${ }^{1}$ Hanoi University of Mining and Geology, No. 18 Vien Street, Duc Thang Ward, Bac Tu Liem District, Hanoi, Vietnam \\ ${ }^{2}$ University of Transport Technology, No. 54 Trieu Khuc, Thanh Xuan District, Hanoi, Vietnam \\ Correspondence should be addressed to Nu Nguyen Thi; nguyenthinu@humg.edu.vn
}

Received 20 January 2020; Accepted 11 March 2020; Published 15 July 2020

Academic Editor: Chuan-Yu Wu

Copyright $\left({ }_{0} 2020 \mathrm{Nu}\right.$ Nguyen Thi et al. This is an open access article distributed under the Creative Commons Attribution License, which permits unrestricted use, distribution, and reproduction in any medium, provided the original work is properly cited.

The horizontal coefficient of consolidation is the most important parameter for designing the improvement of soil soft by prefabricated vertical drains (PVDs) combined with surcharge and vacuum preloading. This paper presents the experimental study on the horizontal coefficient of consolidation $\left(c_{h}\right)$ of some soft soils distributed in Vietnam. The $c_{h}$ value was determined by the laboratory test and CPTu dissipation test. The laboratory tests included the Rowe consolidation cell test and constant rate of strain consolidation with radial drainage test. Two types of consolidation laboratory tests were performed. The experimental results indicated that the $c_{h}$ value is always larger than the vertical coefficient of consolidation of soil $\left(c_{v}\right)$. The ratio of $c_{h} / c_{v}$ depends on the consolidated pressure, type of soil, and the anisotropy of soil. The ratio of $c_{h} / c_{v}$ is different in different types of soft soil in Vietnam. In the normally consolidated state, the $c_{h} / c_{v}$ ratio ranges from 1.35 to 10.59 . It was necessary to choose the $c_{h}$ value at the consolidated stress level for calculating the PVD spacing.

\section{Introduction}

Construction in the soft clayey ground usually makes serious settlement problems [1] because of consolidation and creep phenomenon $[2,3]$. Consolidation settlement induces by dissipation of the excess pore water pressure and creep settlement is caused by viscosity of the soil skeleton [2]. In order to reduce the consolidation settlement, prefabricated vertical drains (PVDs) combined with surcharge and vacuum preloading are widely used in practice engineering. PVDs accelerate the consolidation process of soft soil under preloading and vacuum preloading and control the consolidation rate of soft soil, allowing for radial drainage over short drainage paths [4]. This method uses Barron's theory to design the PVD spacing $[5,6]$ and one of the most important parameters for this design is the horizontal coefficient of consolidation of soft soil $\left(c_{h}\right)$.

In the world, the horizontal coefficient of consolidation of soft soil can be commonly determined by three methods, such as laboratory tests, CPTu dissipation tests, and Asaoka's observational method. Recently, the $c_{h}$ value can be calculated by DMT pressure dissipation tests [7] or pressuremeter [8].

Firstly, in the laboratory, the $c_{h}$ value can be determined by radial consolidation tests [9] with inward or outward drainage in some types of apparatus. Rowe [10] evaluated the $c_{h}$ value from the triaxial cell and conventional oedometer cell. Other researchers [11-14] investigated properties of the horizontal coefficient of consolidation by conventional oedometer cell. Seah and Juirnarongrit [15] developed a constant rate of strain consolidation with radial drainage (CRS-R) consolidometer to determine the consolidation properties of soft Bangkok clay.

In the radially inward test, a sand drain or a fine porous stone was placed at the middle. The diameters of the central drain used are 10,15 , and $50 \mathrm{~mm}$. The time-settlement date obtained from the radially inward consolidation test was analyzed using the $\log t$ method and the $c_{h}$ values were calculated $[16,17]$. In the radially outward test, outward radial flows towards a porous plastic drain placed at the periphery. 
The results of radial consolidation tests were related to several factors, such as the direction and length of drainage, shape of sample, and stress conditions of the test [10]. Other factors that influence $c_{h}$ value are the types of drain diameter and the direction of drainage $[11,14]$. In the radially inward test, the $c_{h}$ value decreased with an increase in drain diameter [14]. The $c_{h}$ values were consistently larger for the inward flow consolidation tests than those in the outward flow consolidation tests [11].

Secondly, the $c_{h}$ values were conducted by CPTu dissipation tests (Torstensson,1975,1977) [18] and then modified by Teh and Houlsby [18, 19]. After that, Balachowski [20] investigated the shape of pore water dissipation for overconsolidated soils and normally consolidated soils and then developed the method to calculate the $c_{h}$ value in soft overconsolidated soils.

Thirdly, Asaoka's observational method was used to evaluate the apparent value of the horizontal coefficient of consolidation $\left(c_{h(a p)}\right)$ [21-23]. The $c_{h(a p)}$ values are lower than those measured by laboratory tests or in situ tests because of the smear effect of PVD installation [24].

It is worth noting that the previous researchers studied the $c_{h}$ value and the ratio of $c_{h} / c_{v}$ of soil. The horizontal coefficient of consolidation of Singapore marine was investigated by laboratory and in situ tests [24]. The $c_{h}$ values were determined by using the Rowe cell with radial drainage to a peripheral plastic drain and CPTu dissipation tests. The results showed that the $c_{h}$ values evaluated from CPTu tests were in good agreement with those obtained from Rowe cell tests. It was also clear that the $c_{h}$ values are different and depend on types of soil.

From the previous literature studies, several researchers studied on the apparatus for determining the horizontal coefficient of consolidation of soil. But, the study on the properties of horizontal consolidation during the different load, the ch value of different soil types, and the factors affected on the $c_{h}$ values is still limited.

In Vietnam, there are very few studies determining the $c_{h}$ value. According to the Vietnamese standard 22TCN 2622000, $c_{h}$ value equals 2 5 times the $c_{v}$ value. However, it is difficult to choose the $c_{h}$ value. Moreover, from the previous studies, it can be found that the $c_{h}$ value depends on the environmental conditions, type of soils, and the origin of soils. So, this paper aimed at determining the horizontal coefficient of consolidation of some soft soil in Vietnam, indicating the factors affect the $c_{h}$ value, and then comparing the value of $c_{h}$ by laboratory tests and CPTu dissipation tests.

\section{Laboratory Tests}

In order to determine the $c_{h}$ value, the Rowe consolidation cell tests and constant rate of strain consolidation with radial drainage tests were used.

Rowe consolidation cell of $62 \mathrm{~mm}$ internal diameter (Figure 1) which met the requirement stipulated in the British standard BS 1377:Part 6 (1990) was used for conducting the radially inward test. The cylinder drainage well of $10 \mathrm{~mm}$ diameter was made by a fine porous stone and the

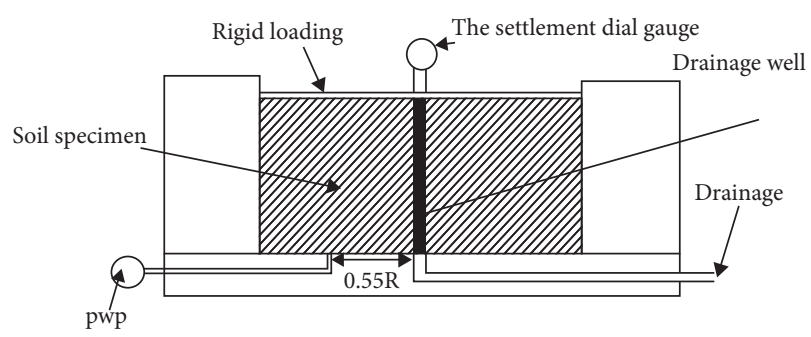

FIgURE 1: The Rowe consolidation cell for radially inward test.

Rowe cell was calibrated as per BS 1377:Part 6 (1990) and Head [25].

The Rowe consolidation cell was placed in position on the bed of the loading apparatus of the traditional oedometer consolidation apparatus. Horizontal consolidation test was conducted according to BS 1377:1990: Part 6. The loading device of the traditional oedometer consolidation apparatus was used. The soil samples were subjected to load consolidation pressures of $12.5,25,50,100,200$, and $400 \mathrm{kPa}$ or so on.

The horizontal coefficient of consolidation (Head [25]), $c_{h}\left(\mathrm{~m}^{2} /\right.$ year $)$, was calculated as follows:

$$
c_{h}=0.131 \frac{D^{2}}{t_{50}} T_{50} \text {, }
$$

where $D$ is the diameter of soil specimen, $\mathrm{mm} ; T_{50}$ is the time factor (in this study, the diameter of central drain $d=10.0 \mathrm{~mm}, D=62 \mathrm{~mm}$, and $T_{50}=0.367$ [25]); and $t_{50}$ represents the time to $50 \%$ degree of consolidation, minutes.

2.1. Constant Rate of Strain Consolidation with Radial Drainage Test. Seah and Juirnarongrit [15] developed a constant rate of strain consolidometer with radial drainage (CSR-R). This consolidation cell of $63.5 \mathrm{~mm}$ inner diameter was used for the radially inward test. The horizontal coefficients of consolidation $\left(c_{h}\right)$ and permeability $\left(k_{h}\right)$ were calculated based on Barron's equal strain theory and were given by

$$
\begin{gathered}
c_{h}=\alpha \frac{v_{p} r_{e}^{2}}{u_{b} H m_{v}}, \\
k_{h}=\alpha \frac{v_{p} \gamma_{w} r_{e}^{2}}{u_{b} H},
\end{gathered}
$$

where $r_{e}$ is the radius of a specimen; $r_{w}$ is the radius of the central drain; $\alpha$ is the ratio of the radius of a specimen to the radius of central drain; $u_{b}$ is the excess pore water pressure at impervious outer boundary; $\gamma_{w}$ is the unit weight of water; $m_{v}$ is the coefficient of volume compressibility; $v_{p}$ is the velocity of load piston; and $H$ is the vertical drainage path.

The average effective vertical stress $\left(\sigma_{v \text {.ave }}^{\prime}\right)$ can be expressed as

$$
\sigma_{v \text {.ave }}^{\prime}=\frac{P}{A}-\beta u_{b}
$$


$\alpha$ and $\beta$ are constant as function of $r_{w}$ and $r_{e}$, in this study, $r_{w}=5.0 \mathrm{~mm}$ and $r_{e}=31.75 \mathrm{~mm}, \alpha=0.680, \beta=0.846$.

\section{CPTu Dissipation Tests}

Cone penetration test with pore pressure measurements (CPTu) was supplemented with a dissipation test. When the penetration was stopped at a given depth, one can monitor the dissipation of the induced pore pressure to the hydrostatic one. Two shapes of the dissipation curve, monotonic decay, or dilatory pore pressure response were recorded, related to the soil stress state and history [20].

The normalized excess pore pressure was defined as follows (Lunne, 1997) [20]:

$$
U=\frac{u_{t}-u_{0}}{u_{i}-u_{0}} \cdot 100 \%
$$

where $u_{t}$ is the water pore pressure measured in time $t ; u_{0}$ is the equilibrium pore pressure in situ; $u_{i}$ is the initial water pore pressure at the beginning of dissipation $t=0$.

The horizontal coefficient of consolidation was determined due to the shape of the dissipation curve in normally consolidated soils or overconsolidated soils.

3.1. Dissipation Test in Normally Consolidated Soils. The shape of dissipation curve shows that a monotonic decay of pore pressure was observed and octahedric component of excess pore pressure was always positive and decreased during dissipation tests [26]. Using the strain path method, the consolidation coefficient in a horizontal direction $\left(c_{h}\right)$ was calculated depending on the rigidity index $\left(I_{r}\right)$ as follows [18]:

$$
c_{h}=\frac{T_{50}^{*} \times \sqrt{I_{r}}}{T_{50}} \times r_{0}^{2},
$$

where $T_{50}^{*}$ is the time factor, $T_{50}^{*}=0.245 ; t_{50}$ is the measured time for $50 \%$ dissipation; $r_{0}$ is the penetrometer radius, $r_{0}=0.0178 \mathrm{~m}$; and $I_{r}$ is the rigidity index.

$$
I_{r}=\frac{G}{S_{u}},
$$

where $G$ is the shear modulus at the strain level induced in the soil by penetration of the probe.

$$
\begin{aligned}
& G=\frac{E}{2(1+v)} \\
& E=\frac{(1+v)(1-2 v)}{(1-v)} E_{\mathrm{oed}},
\end{aligned}
$$

where $E$ is the elastic modulus; $E_{\text {oed }}$ is the oedometer modulus; $v$ is Poisson's ratio; and $S_{u}$ is the undrained shear strength; the rigidity index can be calculated using plasticity index $I_{p}$ and estimated OCR [20].

$$
I_{r}=\frac{\exp \left[\left(137-I_{p}\right) / 23\right]}{\left[1+\ln \left\{1+\left((\mathrm{OCR}+1)^{3.2} / 26\right)\right\}\right]^{0.8}} .
$$

3.2. Dissipation Test in Soft Overconsolidated Soils. The shape of dissipation curve shows that the excess pore pressure was initially increasing in overconsolidated soils (dilatory response) and after that, the pore pressure decreased during dissipation tests. The coefficient of consolidation in a horizontal direction was determined from the modified time factor $T^{*}$ (Mayne,) $2001[20,26]$ :

$$
T^{*}=\frac{c_{h} \times t}{r_{0}^{2}\left(I_{r}\right)^{0.75}}
$$

The pore water dissipation curve at any time $t$ was fitted in equation (9) for a given rigidity index. The best fit value of $c_{h}$ was obtained with trial and error procedure.

\section{Materials and Testing Program}

4.1. Materials. For laboratory tests, soft soil samples were collected from the boreholes in Ha Tinh province (Site 1), Tien Giang province (Site 2), Tra Vinh province (Site 3), Soc Trang province (Site 4 and Site 5), Ca Mau province (Site 6), and Kien Giang province (Site 7). High-quality undisturbed samples were taken at different depths by using $0.75 \mathrm{~m}$ long thin-walled piston samples from the boreholes.

Soil particle and physical properties of these samples were determined. The tests were conducted according to the ASTM standards. Some properties and particle content of these soils are illustrated in Figures 2(a) 2(g).

From experimental results, it can be found that the natural moisture content is greater than the liquid limit at most depths in at seven sites. The natural moisture content of soft soil is extremely variable and the void ratio is higher than 1. It can be also found that the Atterberg limits vary with depth. The soil types belong to clay or sandy clay in the soft state.

4.2. Testing Program. There are three steps in this study. Firstly, two types of laboratory consolidation tests on the undisturbed soft soil samples were performed. Two samples were tested by two types of equipment for comparing the results from the Rowe consolidation cell test and the CRS-R test at Site 1 and Site 6. Secondly, the CPTu dissipation tests were performed at Site 4. Twelve CPTu dissipation tests at four series of CPTu tests (CPTu-01, CPTu-02, CPTu-03, and $\mathrm{CPTu}-04)$ were conducted. After that, at the same depth in the near boreholes, soil samples were taken and were used for Rowe consolidation tests and traditional oedometer tests. This study was used for comparing the $c_{h}$ values between $\mathrm{CPTu}$ dissipation tests and Rowe consolidation tests and determining the ratio of $c_{h} / c_{v}$. Thirdly, all samples at seven sites determined both the horizontal and the vertical coefficient of consolidation. The horizontal coefficient of consolidation was tested by Rowe consolidation cell and the vertical coefficient of consolidation was conducted by standard oedometer tests. After that, the ratio of $c_{h} / c_{v}$ was calculated.

In the CRS-R test, before testing, the soil specimen was applied a back pressure of $200 \mathrm{kPa}$ for saturation over a period of $24 \mathrm{~h}$. After that, the soil specimen was loaded by a gear driven loading frame that forced the loading piston to 

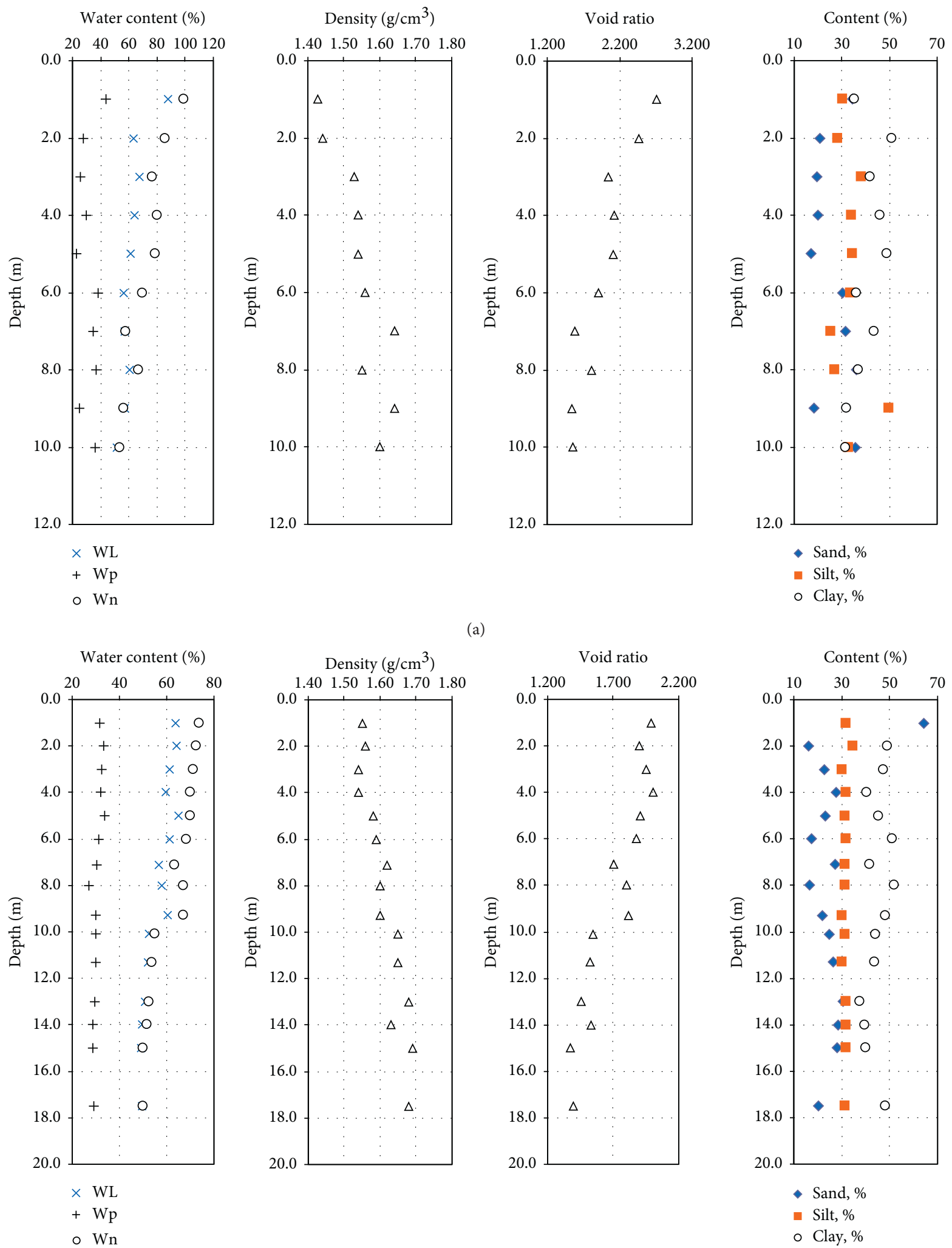

(b)

Figure 2: Continued. 

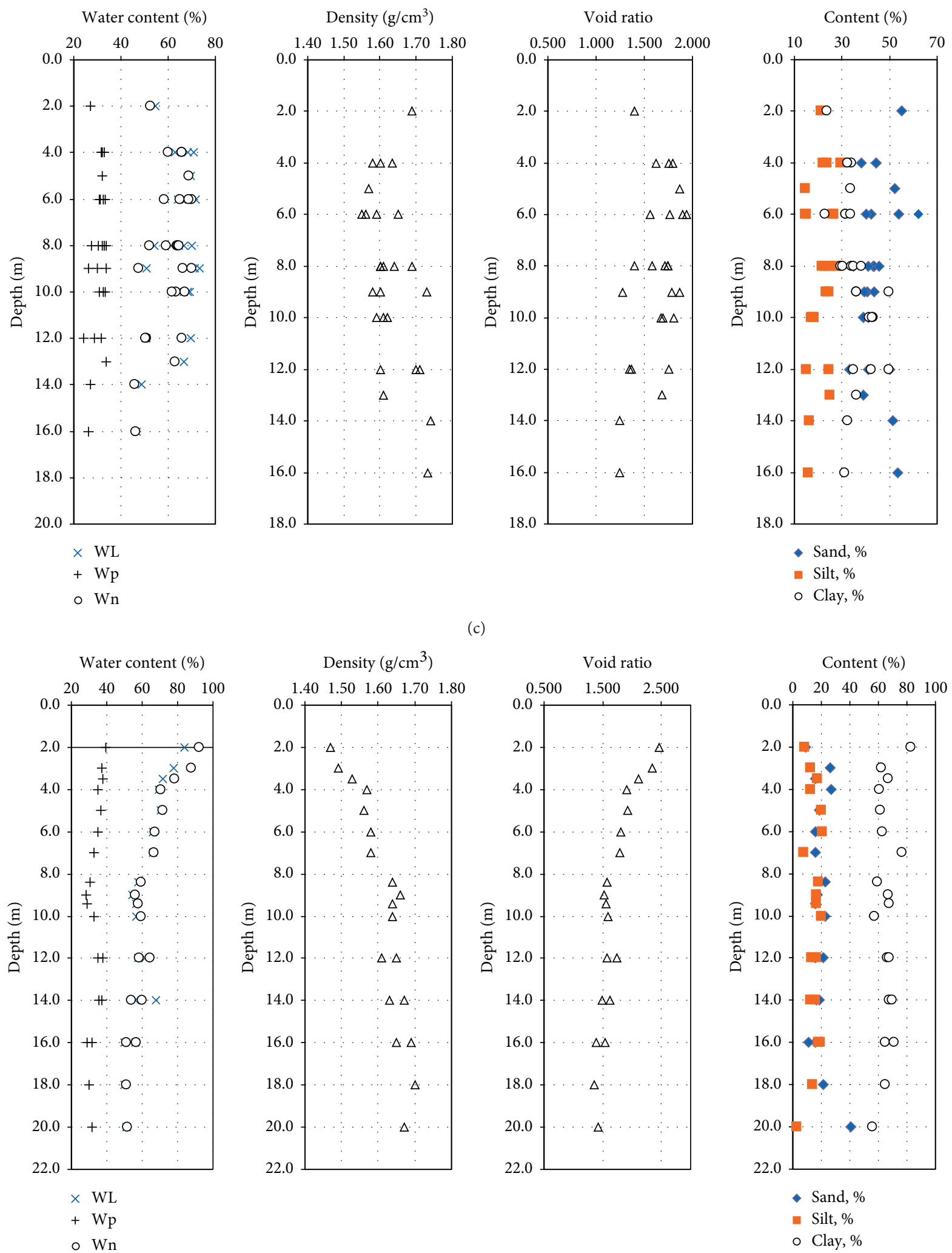

(d)

Figure 2: Continued. 

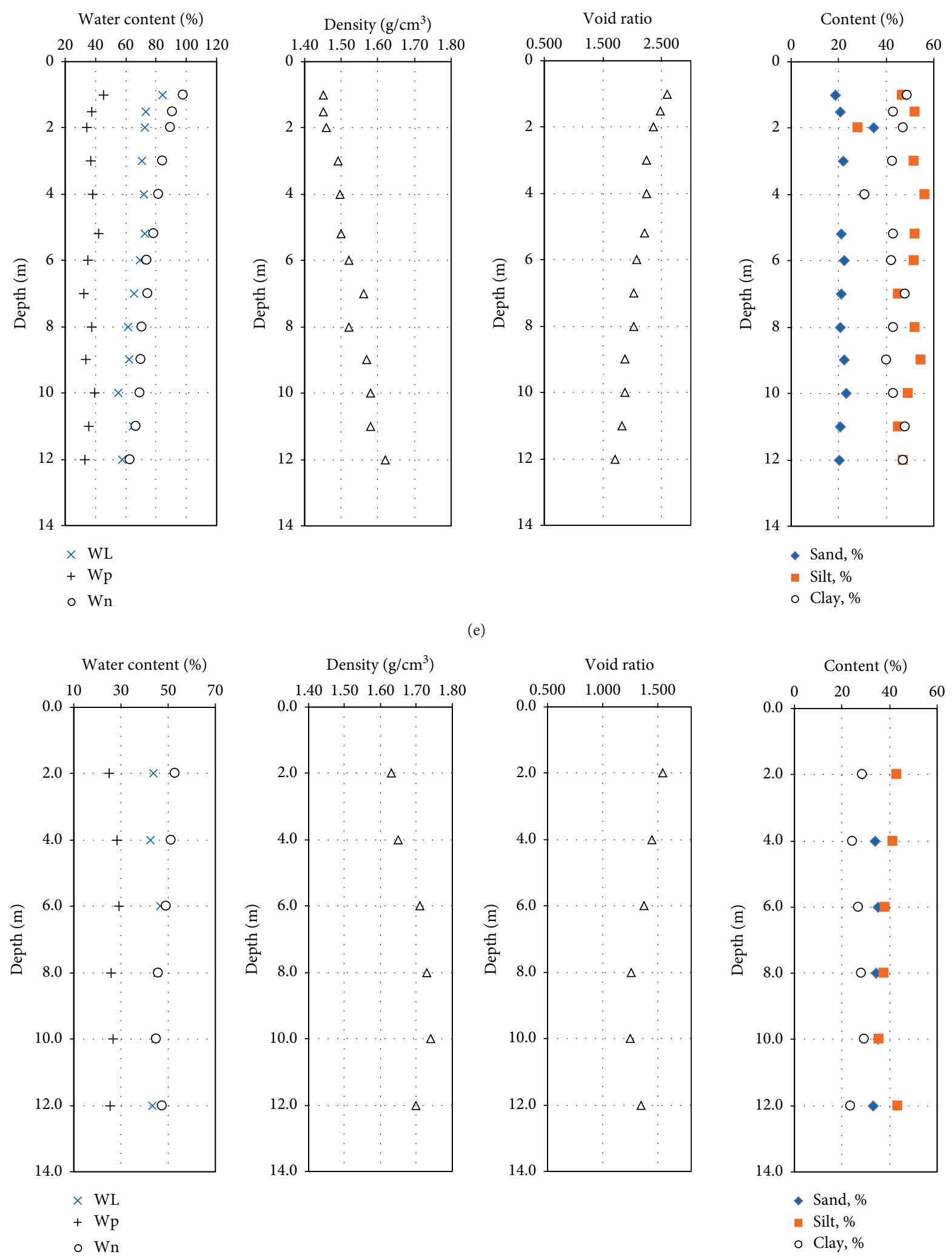

(f)

Figure 2: Continued. 

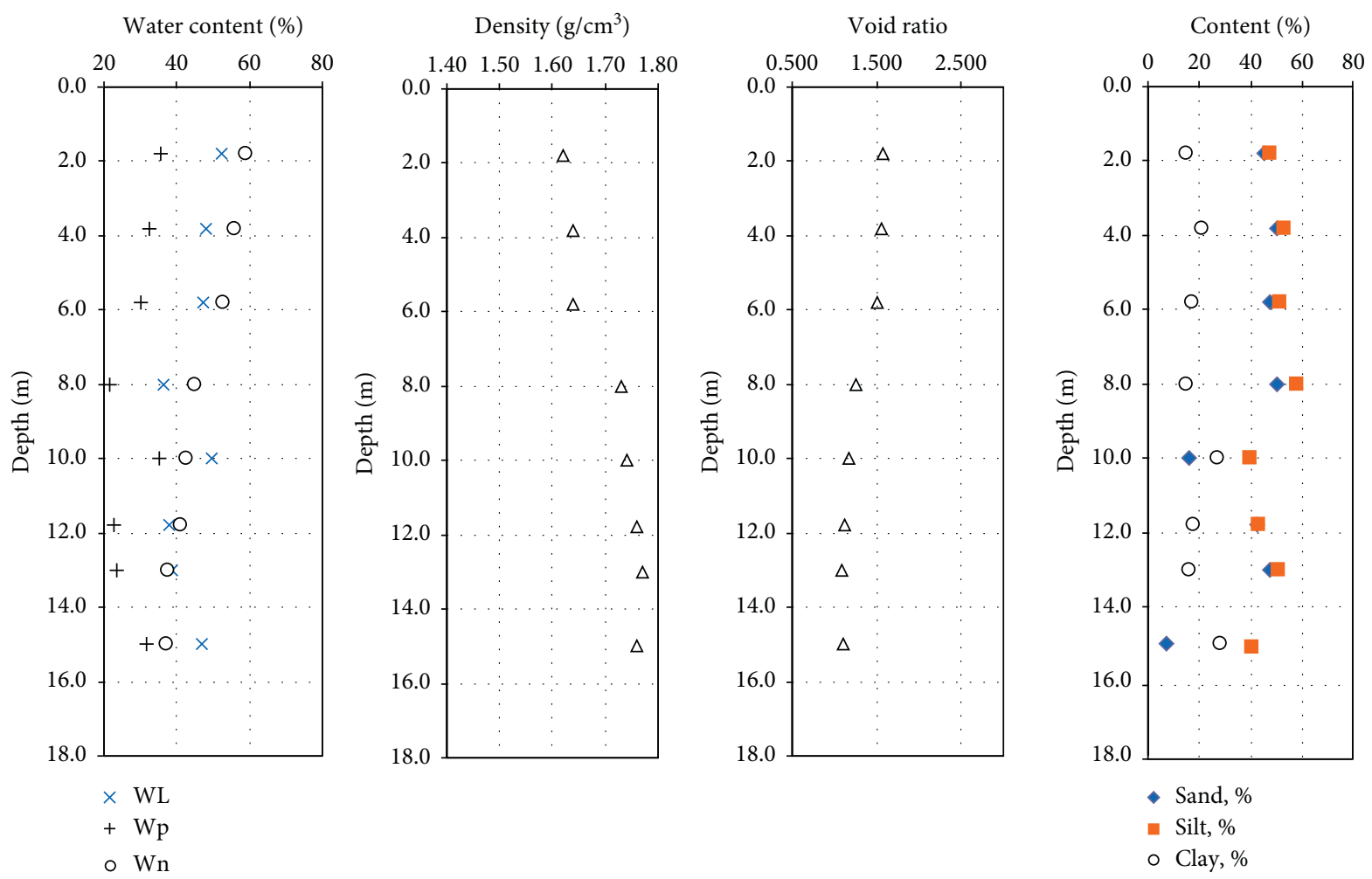

(g)

Figure 2: (a) The physical properties and particles of soft clay in Tien Giang province (Site 2). (b) The physical properties and particles of soft clay in Tra Vinh province (Site 3). (c) The physical properties and particles of soft clay in Soc Trang province (Site 4). (d) The physical properties and particles of soft clay in Ca Mau province (Site 6). (e) The physical properties and particles of soft clay in Kien Giang province (Site 7). (f) The physical properties and particles of soft sandy clay in Ha Tinh province (Site 1). (g) The physical properties and particles of soft sandy clay in Soc Trang province (Site 5).

move downward at a constant speed. The CRS-R consolidation test was performed on soil samples at a constant speed of $0.0036 \mathrm{~mm} /$ minute.

The conventional tests were conducted with incremental loading, each increment was equal to the previous load, and a new increment of load was applied every 24 hours for determining the $c_{h}$ value and the $c_{v}$ value. The tests were performed in accordance with ASTM D2435. The horizontal coefficient of consolidation was tested by Rowe consolidation cell and the vertical coefficient of consolidation was conducted by the incremental load oedometer. For comparing the results from these apparatuses, the series loads used in this study were $12.5,25,50,100,200$, and $400 \mathrm{kPa}$. The load-increment ratio was 1 .

\section{Result and Discussion}

Firstly, Figure 3 represents the horizontal and vertical coefficient of consolidation of soft soil at Site 6 and Site 1. It can be shown that the $c_{h}$ value derived from the Rowe cell test agrees well with that from CRS-R test. It was also found that the $c_{h}$ values are higher than the $c_{v}$ values at different consolidation pressures.

Secondly, in order to determine the consolidation properties of soft soil in the in situ test, at Site 4 (Soc Trang province), CPTu dissipation tests were performed. The shape of dissipation test is provided in Figure 4. It can be shown that the shape is similar to the test in normally consolidated soil.

The horizontal coefficient of consolidation was calculated by CPTu dissipation test as shown in Table 1. Table 1 also shows the horizontal coefficient of consolidation of Rowe cell and the vertical coefficient of consolidation $\left(c_{v}\right)$.

As shown in Table 1, it can be found that the horizontal coefficient of consolidation was calculated by CPTu dissipation test ( $c_{h \text { (CPTu test) }}$ ) equals 0.39 to 1.98 times $c_{h \text { (Rowe test). }}$ The average of $c_{h \text { (CPTu test) }}$ is equal to 1.14 times the $c_{h \text { (Rowe }}$ test). It was similar to the result of Chu et al. [23] that the $c_{h}$ value derived from the CPTu dissipation test agrees well with that from of Rowe cell and $c_{h}$ value of Rowe cell was generally lower than that from other in situ tests. It was believed to be due to the too costly stratification or the fabric of the soils, and the $c_{h}$ values measured by CPTu test indicated the $c_{h}$ values in the overconsolidated (OC) range [27]. It also may be due to the smear effect [24] or stress level [28]. It was consistent with the results of Seah and Juirnarongrit [15] that the horizontal coefficient of consolidation from field piezoprobe tests was in good agreement with the results from the laboratory CRS-S test. 


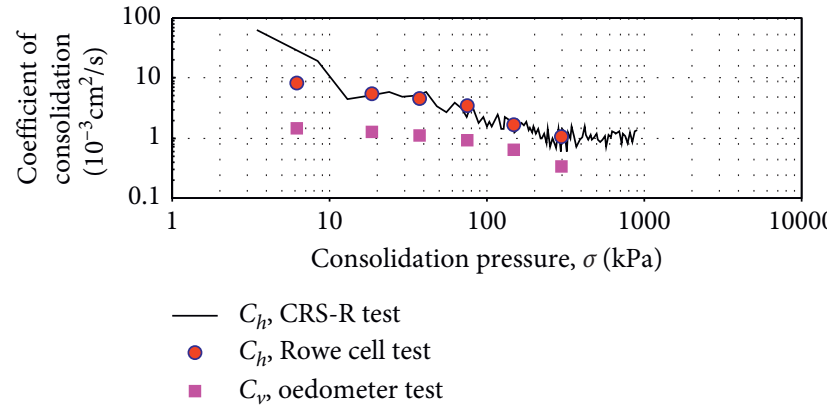

(a)

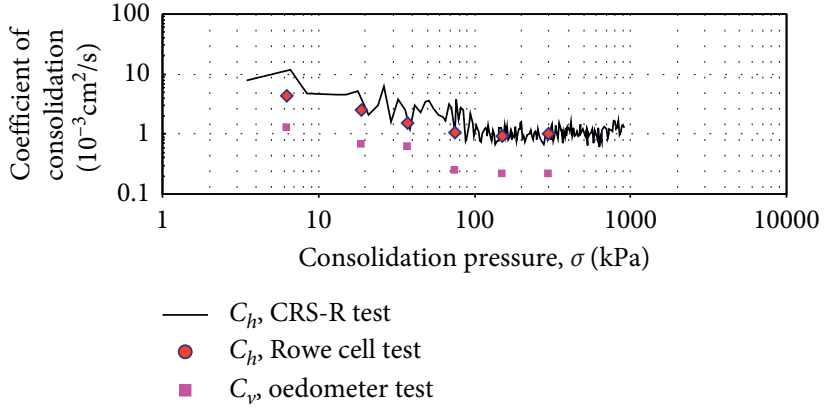

(b)

Figure 3: (a) The coefficient of consolidation of soft clay in Ca Mau province (Site 6). (b) The coefficient of consolidation of soft sandy clay in Ha Tinh province (Site 1).

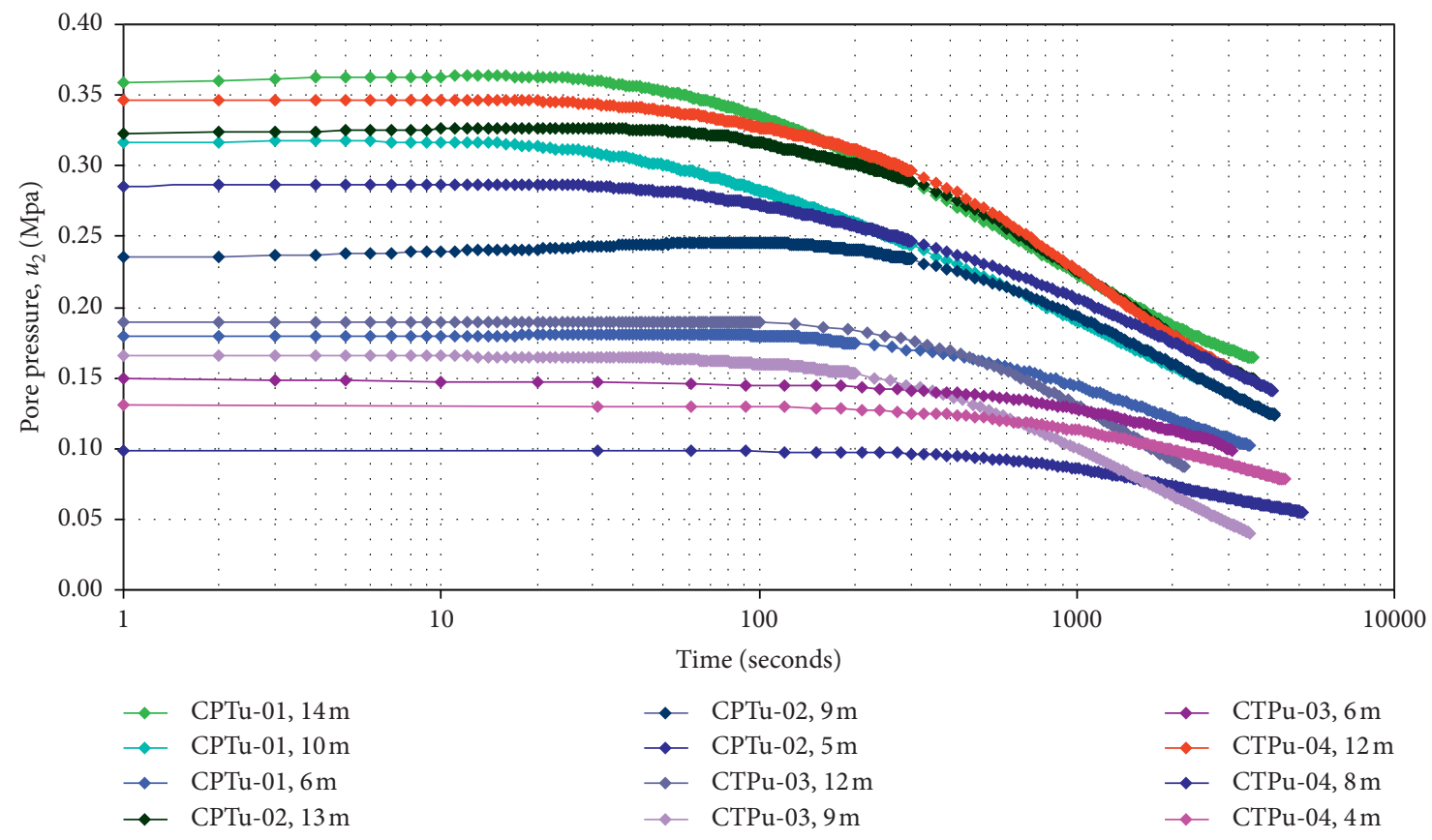

Figure 4: Dissipation curves with logarithm of time plot correction in Soc Trang province (Site 4).

TABLE 1: The consolidation properties of soft soil at Site 4 determined by two methods.

\begin{tabular}{|c|c|c|c|c|c|c|c|c|c|c|}
\hline \multirow[b]{2}{*}{ No } & \multirow[b]{2}{*}{$\begin{array}{l}\text { Depth } \\
H(\mathrm{~m})\end{array}$} & \multirow[b]{2}{*}{$\begin{array}{c}\text { Effective } \\
\text { stress } \sigma^{\prime} \\
(\mathrm{kPa})\end{array}$} & \multicolumn{4}{|c|}{ CPTu dissipation test } & \multirow[b]{2}{*}{$\begin{array}{c}\text { Horizontal coefficient } \\
\text { of } \\
\text { consolidation-Rowe } \\
\text { test } c_{h} \\
\mathrm{~m}^{2} / \text { year }\end{array}$} & \multirow[b]{2}{*}{$\begin{array}{c}\text { Vertical } \\
\text { coefficient of } \\
\text { consolidation } \\
c_{v}\end{array}$} & \multicolumn{2}{|c|}{ Ratio of $c_{h} / c_{v}$} \\
\hline & & & $\begin{array}{c}\text { Max } \\
\text { water } \\
\text { pore } \\
\text { pressure } \\
u_{i}(\mathrm{kPa})\end{array}$ & $\begin{array}{c}\text { Initial } \\
\text { water } \\
\text { pore } \\
\text { pressure } \\
u_{0}(\mathrm{kPa})\end{array}$ & $\begin{array}{l}T_{50} \\
(\mathrm{~s})\end{array}$ & $\begin{array}{c}\text { Horizontal } \\
\text { coefficient of } \\
\text { consolidation } \\
c_{h}\end{array}$ & & & CPTu & $\begin{array}{c}\text { Rowe } \\
\text { test }\end{array}$ \\
\hline \multirow{4}{*}{ CPTu-01 } & 6 & 38.4 & 181 & 30 & 3156 & 3.09 & 4.70 & 1.65 & 1.87 & 2.85 \\
\hline & 10 & 64.0 & 318 & 70 & 946 & 10.32 & 7.03 & 1.57 & 6.57 & 4.48 \\
\hline & 14 & 89.6 & 364 & 110 & 795 & 12.28 & 6.21 & 2.47 & 4.97 & 2.51 \\
\hline & 5 & 32.0 & 98 & 20 & 5011 & 1.95 & 4.95 & 1.15 & 1.70 & 4.30 \\
\hline \multirow[t]{3}{*}{ CPTu-02 } & 9 & 57.6 & 245 & 60 & 2296 & 4.25 & 3.36 & 1.13 & 3.76 & 2.97 \\
\hline & 13 & 83.2 & 326 & 100 & 1216 & 8.03 & 8.35 & 1.96 & 4.10 & 4.26 \\
\hline & 6 & 38.4 & 150 & 50 & 3985 & 2.45 & 3.88 & 1.34 & 1.83 & 2.90 \\
\hline \multirow[t]{3}{*}{ CPTu-03 } & 9 & 57.6 & 153 & 80 & 795 & 12.28 & 11.51 & 3.06 & 4.01 & 3.76 \\
\hline & 12 & 76.8 & 190 & 110 & 855 & 11.42 & 7.30 & 2.18 & 5.24 & 3.35 \\
\hline & 4 & 25.6 & 132 & 30 & 4875 & 2.00 & 1.39 & 1.00 & 2.00 & 1.39 \\
\hline \multirow[t]{2}{*}{ CPTu-04 } & 8 & 51.2 & 287 & 70 & 1845 & 5.29 & 5.00 & 2.01 & 2.63 & 2.49 \\
\hline & 12 & 76.8 & 347 & 110 & 975 & 10.01 & 9.41 & 2.24 & 4.47 & 4.20 \\
\hline Average & & & & & & 6.95 & 6.09 & 1.81 & 3.83 & 3.36 \\
\hline
\end{tabular}




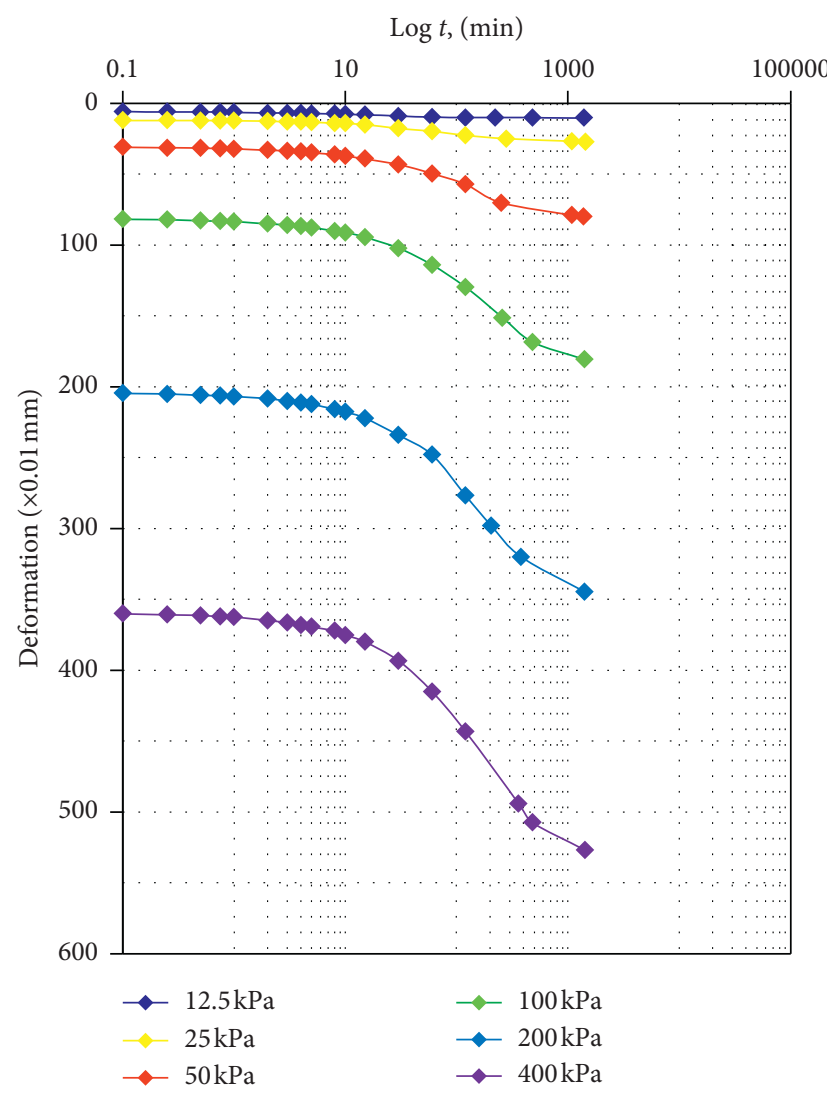

(a)

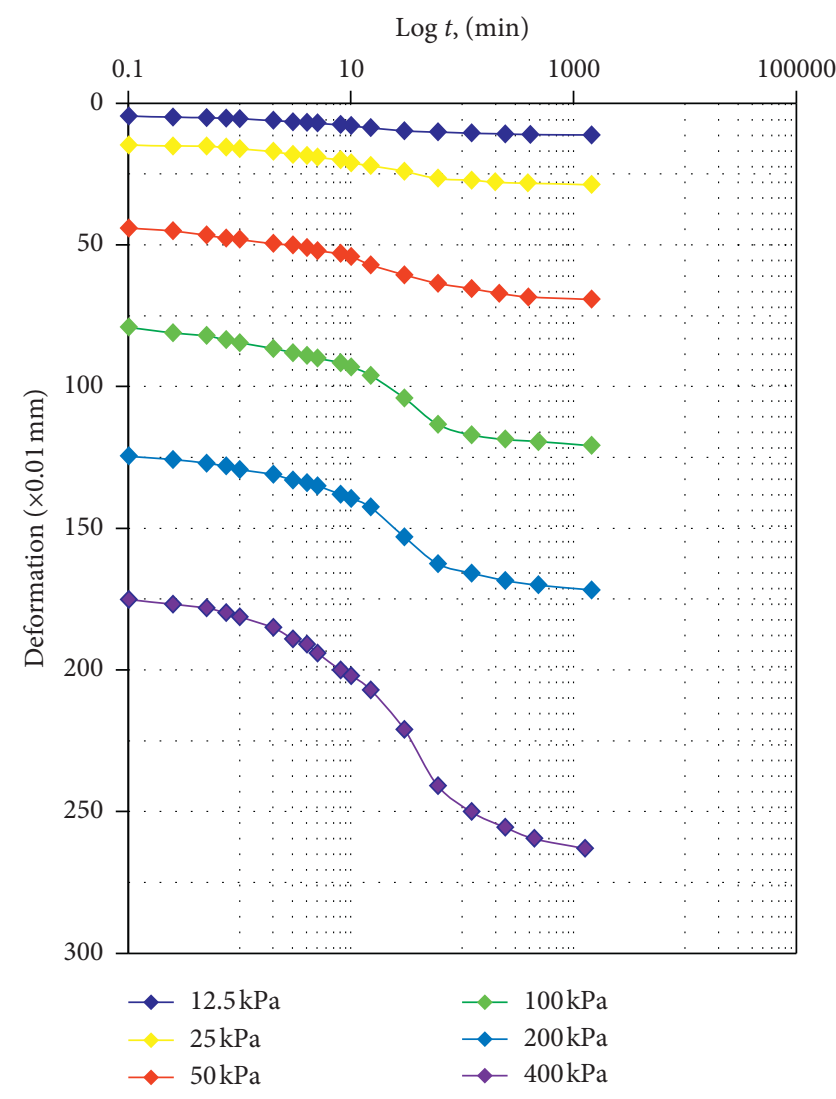

(b)

Figure 5: Relationship of deformation and time. (a) Clay soil sample (depth: $2 \mathrm{~m}$-Site 2). (b) Sandy clay sample (depth: $6 \mathrm{~m}-$ Site 5).

From the experimental results, as also provided in Table 1, it was noticed that the ratio of horizontal to vertical coefficient of consolidation $\left(c_{h \text { (CPTu test) }} / c_{v}\right)$ of soft clay for Site 4 varies from 1.70 6.58, and the ratio of $c_{h \text { (Rowe test }) / c_{v}}$ ranges from $1.39 \sim 4.48$. The ratio of $c_{h \text { (CPTu test) }} / c_{v}$ equals 1.14 times the ratio of $c_{h \text { (Rowe test })} / c_{v}$.

Thirdly, the coefficient of consolidation of soft soil at seven sites in Vietnam was determined by the Rowe consolidation cell. The time-deformation graph plotted for each load increment is presented in Figure 5. The variation of horizontal coefficient of consolidation, vertical coefficient of consolidation, and the ratio of $c_{h} / c_{v}$ with the consolidation pressure was determined by conventional tests, as shown in Table 2.

From the results provided in Table 2, it can be seen that the $c_{h}$ value of soft clay for Site 2 varies from $2.00 \sim 15.88 \mathrm{~m}^{2} /$ year, for Site 3 from $1.77 \sim 14.54 \mathrm{~m}^{2} /$ year, for Site 4 from $1.27 \sim 30.48 \mathrm{~m}^{2} /$ year, for Site 6 from $2.37 \sim 18.51 \mathrm{~m}^{2} /$ year, and for Site 7 from $1.28 \sim 21.79 \mathrm{~m}^{2} /$ year. It can be found that the horizontal heterogeneity of soil at Site 4 is the highest.

Similarly, the $c_{h}$ values of soft sandy soil for Site 1 and Site 5 range from $3.09 \sim 30.49 \mathrm{~m}^{2} /$ year and $2.34 \sim 23.60 \mathrm{~m}^{2}$ / year, respectively.

As shown in Figure 6, it can be found that the $c_{h}$ values decrease from over consolidated range to normally consolidated range. It was also seen that the $c_{h}$ values decrease with increasing vertical effective stress. This is consistent with the research results indicated by Seah et al [28] and it was found that the soft Bangkok clay was slightly anisotropic.

The mean value of the horizontal coefficient of consolidation was determined by the Rowe cell test ranging from 1.11 to 10.59 times the vertical coefficient of consolidation. Chu at el. [24] indicated that $c_{h}$ of Singapore's marine clay was generally $2 \sim 4$ times larger than $c_{v}$ by the conventional oedometer test. It was believed that the $c_{h}$ value is higher than $c_{v}$ due to the anisotropic nature of the soil (Figures 7 9).

The variations in the ratio of $c_{h} / c_{v}$ of soft clay soil are also provided in Table 2. It can be seen that there are the differences in $c_{h} / c_{v}$ at different sites; the smallest range of $c_{h} / c_{v}$ is from 1.64 4.05 at Site 2 and the largest range of $c_{h} /$ $c_{v}$ is from 1.47 10.59 at Site 3, while the range of $c_{h} / c_{v}$ at Sites 4,6 , and 7 is from $1.35 \sim 6.49,2.02 \sim 5.98$, and $2.46 \sim 10.52$, respectively. It can be believed that the anisotropic of soil decreases from Sites 3, 7, 4, and 6 to Site 2 . The soil at Site 3 is more anisotropic due to the presence of interlaced thin layers of sand. Sand dunes in an unstable environment in the coastal estuaries are important factors for the horizontal coefficient of consolidation of soft soil. At Site 7 (Figure 9), the soil has highest anisotropic due to the presence of organic matter. The soil has been deposited in a quiet environment with many coastal swamp plants. After that, the dead coastal swamp 
TABLE 2: The consolidation properties of soft soil at different sites in Vietnam.

\begin{tabular}{|c|c|c|c|c|c|c|c|c|c|c|}
\hline \multirow[t]{2}{*}{ The coefficient of consolidation } & \multirow{2}{*}{$\begin{array}{l}\text { Consolidation pressure, } \sigma \\
\qquad(\mathrm{kPa})\end{array}$} & \multicolumn{3}{|c|}{$\begin{array}{l}\text { The vertical } \\
\text { coefficient of } \\
\text { consolidation }\end{array}$} & \multicolumn{3}{|c|}{$\begin{array}{l}\text { The horizontal } \\
\text { coefficient of } \\
\text { consolidation }\end{array}$} & \multicolumn{3}{|c|}{ Ratio of $c_{h} / c_{v}$} \\
\hline & & $\begin{array}{c}\text { Averag } \\
\quad c_{v},\end{array}$ & $\begin{array}{l}\text { Max } \\
\mathrm{m}^{2} / \text { year }\end{array}$ & Min & $\begin{array}{r}\text { Averag } \\
\quad c_{h},\end{array}$ & $\begin{array}{l}\text { Max } \\
\mathrm{n}^{2} / \text { year }\end{array}$ & Min & Average & Max & Min \\
\hline \multicolumn{11}{|c|}{ Soft clay-Tien Giang (Site 2). Soluble salt content of $0.20 \sim 0.97 \%$; organic matter content of 3.50 7.20\%. Number of samples $=10$} \\
\hline \multirow{6}{*}{$\begin{array}{l}\text { The coefficient of consolidation at } \sigma \\
\left(\mathrm{m}^{2} / \text { year }\right)\end{array}$} & $0-12.5$ & 4.68 & 12.71 & 1.75 & 9.98 & 15.88 & 6.10 & 2.60 & 5.03 & 1.25 \\
\hline & $12.5-25$ & 2.57 & 7.09 & 1.37 & 6.56 & 10.44 & 5.30 & 2.94 & 4.44 & 1.47 \\
\hline & $25-50$ & 1.65 & 2.99 & 0.77 & 5.16 & 7.85 & 2.20 & 3.44 & 5.79 & 1.98 \\
\hline & $50-100$ & 1.16 & 1.59 & 0.68 & 3.22 & 4.04 & 2.22 & 2.84 & 3.61 & 1.83 \\
\hline & $100-200$ & 1.04 & 1.43 & 0.77 & 2.72 & 3.59 & 2.00 & 2.72 & 3.73 & 1.64 \\
\hline & $200-400$ & 0.96 & 1.32 & 0.66 & 2.81 & 3.28 & 2.04 & 3.05 & 4.05 & 2.06 \\
\hline
\end{tabular}

Soft clay-Tra Vinh (Site 3). Soluble salt content of 0.10 0.25\%; organic matter content of 0.91 3.35\%. Number of samples $=15$

\begin{tabular}{|c|c|c|c|c|c|c|c|c|c|c|}
\hline \multirow{6}{*}{$\begin{array}{l}\text { The coefficient of consolidation at } \sigma \\
\left(\mathrm{m}^{2} / \text { year }\right)\end{array}$} & $0-12.5$ & 2.75 & 7.22 & 0.85 & 7.63 & 14.54 & 2.59 & 3.79 & 7.65 & 1.83 \\
\hline & $12.5-25$ & 1.80 & 3.56 & 0.66 & 4.64 & 7.66 & 1.77 & 3.00 & 7.11 & 1.21 \\
\hline & $25-50$ & 1.87 & 3.53 & 0.88 & 4.86 & 9.97 & 1.86 & 2.89 & 7.59 & 1.42 \\
\hline & $50-100$ & 1.85 & 3.66 & 0.98 & 5.54 & 12.55 & 2.55 & 3.27 & 8.29 & 1.62 \\
\hline & $100-200$ & 1.65 & 3.15 & 0.95 & 5.62 & 10.76 & 1.89 & 3.84 & 10.00 & 1.62 \\
\hline & $200-400$ & 1.89 & 4.07 & 0.91 & 5.69 & 10.09 & 1.58 & 3.64 & 10.59 & 1.47 \\
\hline \multicolumn{11}{|c|}{ Soft clay-Soc Trang (Site 4). Soluble salt content of $0.21 \sim 1.95 \%$; organic matter content of $0.60 \sim 5.89 \%$. Number of samples $=26$} \\
\hline \multirow{6}{*}{$\begin{array}{l}\text { The coefficient of consolidation at } \sigma \\
\left(\mathrm{m}^{2} / \text { year }\right)\end{array}$} & $0-12.5$ & 3.19 & 7.92 & 1.00 & 13.26 & 30.48 & 7.59 & 4.91 & 9.80 & 2.23 \\
\hline & $12.5-25$ & 2.33 & 6.36 & 0.94 & 6.07 & 11.48 & 1.74 & 2.95 & 5.76 & 1.27 \\
\hline & $25-50$ & 1.86 & 4.31 & 0.86 & 5.39 & 13.46 & 1.27 & 2.91 & 6.55 & 1.14 \\
\hline & $50-100$ & 1.56 & 3.06 & 0.88 & 5.40 & 9.41 & 3.17 & 3.57 & 6.49 & 2.16 \\
\hline & $100-200$ & 1.44 & 2.90 & 0.77 & 5.24 & 7.73 & 2.93 & 3.94 & 6.01 & 1.91 \\
\hline & $200-400$ & 1.37 & 2.64 & 0.59 & 4.64 & 7.59 & 2.46 & 3.75 & 6.09 & 1.35 \\
\hline \multicolumn{11}{|c|}{ Soft clay-Ca Mau (Site 6). Soluble salt content of 1.46 2.32\%; organic matter content of 1.60 8.00\%. Number of samples $=19$} \\
\hline \multirow{6}{*}{$\begin{array}{l}\text { The coefficient of consolidation at } \sigma \\
\left(\mathrm{m}^{2} / \text { year }\right)\end{array}$} & $0-12.5$ & 3.61 & 10.20 & 1.45 & 12.37 & 18.51 & 3.27 & 4.15 & 8.78 & 1.13 \\
\hline & $12.5-25$ & 2.08 & 4.15 & 1.01 & 6.21 & 15.90 & 2.76 & 3.03 & 4.80 & 1.11 \\
\hline & $25-50$ & 1.57 & 2.76 & 0.72 & 5.35 & 9.79 & 3.47 & 3.65 & 6.73 & 1.42 \\
\hline & 50-100 & 1.09 & 2.51 & 0.72 & 4.09 & 5.98 & 2.74 & 3.83 & 5.01 & 2.02 \\
\hline & $100-200$ & 0.89 & 1.64 & 0.64 & 3.46 & 4.89 & 2.37 & 3.99 & 5.98 & 2.51 \\
\hline & $200-400$ & 0.90 & 1.59 & 0.67 & 3.32 & 4.25 & 2.54 & 3.80 & 4.92 & 2.03 \\
\hline
\end{tabular}

Soft clay with organic matter-Kien Giang (Site 7). Soluble salt content of 1.42 2.48\%; organic matter content of 11.5 30.0\%. Number of

\begin{tabular}{|c|c|c|c|c|c|c|c|c|c|c|}
\hline & & $=13$ & & & & & & & & \\
\hline & $0-12.5$ & 2.01 & 3.27 & 0.74 & 14.32 & 21.79 & 6.85 & 7.96 & 9.26 & 6.66 \\
\hline & $12.5-25$ & 1.28 & 1.93 & 0.62 & 11.53 & 16.50 & 6.57 & 9.53 & 10.52 & 8.55 \\
\hline The coefficient of consolidation at $\sigma$ & $25-50$ & 0.83 & 1.12 & 0.54 & 7.26 & 9.79 & 4.74 & 8.81 & 8.85 & 8.77 \\
\hline$\left(\mathrm{m}^{2} /\right.$ year $)$ & $50-100$ & 0.65 & 0.79 & 0.52 & 3.14 & 3.19 & 3.08 & 5.01 & 5.96 & 4.06 \\
\hline & $100-200$ & 0.48 & 0.60 & 0.37 & 1.92 & 2.56 & 1.28 & 3.86 & 4.27 & 3.44 \\
\hline & $200-400$ & 0.52 & 0.53 & 0.50 & 2.14 & 2.97 & 1.31 & 4.17 & 5.89 & 2.46 \\
\hline I & ntent of & ; org & mat & $\mathrm{co}$ & at of 0 & $8 \sim 4.7$ & $5 \% . \mathrm{N}$ & nber & samp & $s=6$ \\
\hline & $0-12.5$ & 5.75 & 8.47 & 2.97 & 11.66 & 30.49 & 9.40 & 3.29 & 3.93 & 2.80 \\
\hline & $12.5-25$ & 5.17 & 7.49 & 2.86 & 9.72 & 21.03 & 5.89 & 2.38 & 3.24 & 1.73 \\
\hline The coefficient of consolidation at $\sigma$ & $25-50$ & 4.92 & 7.72 & 2.82 & 6.89 & 14.07 & 4.65 & 1.92 & 2.32 & 1.65 \\
\hline$\left(\mathrm{m}^{2} /\right.$ year $)$ & $50-100$ & 4.22 & 6.12 & 2.64 & 4.86 & 17.90 & 3.56 & 2.38 & 3.12 & 1.35 \\
\hline & $100-200$ & 3.78 & 5.76 & 1.79 & 3.99 & 15.65 & 3.66 & 2.54 & 3.05 & 2.05 \\
\hline & $200-400$ & 3.68 & 6.15 & 1.14 & 3.09 & 14.32 & 3.09 & 2.63 & 3.12 & 2.07 \\
\hline Soft sandy clay with sand and organ & $\begin{array}{r}\text { c Trang ( } \\
5.31 \% .\end{array}$ & sam & $\begin{array}{l}\text { onter } \\
s=8\end{array}$ & $\mathrm{fo}$ & 1.79 & $\mathrm{cga}$ & & & & $2 \% \sim$ \\
\hline & $0-12.5$ & 2.10 & 4.48 & 0.85 & 11.03 & 16.82 & 8.08 & 7.26 & 9.65 & 3.75 \\
\hline & $12.5-25$ & 1.54 & 2.92 & 0.79 & 10.94 & 23.60 & 4.60 & 6.30 & 8.08 & 5.01 \\
\hline The coefficient of consolidation at $\sigma$ & $25-50$ & 1.67 & 3.35 & 0.80 & 7.87 & 14.23 & 4.69 & 5.22 & 5.85 & 4.25 \\
\hline$\left(\mathrm{m}^{2} /\right.$ year $)$ & $50-100$ & 1.45 & 2.79 & 0.69 & 6.32 & 10.85 & 4.06 & 4.83 & 5.91 & 3.88 \\
\hline & $100-200$ & 1.32 & 2.61 & 0.66 & 5.18 & 10.11 & 2.71 & 3.99 & 4.12 & 3.87 \\
\hline & $200-400$ & 0.80 & 1.03 & 0.63 & 3.02 & 3.51 & 2.34 & 3.95 & 5.56 & 3.13 \\
\hline
\end{tabular}

plants decomposed and formed organic matter in soil. It may be due to the fact that the pronounced structural anisotropy for the fibrous peat with the voids spaces in the horizontal direction was larger than those in the vertical direction resulting from the fiber orientation with the soil [29]. 


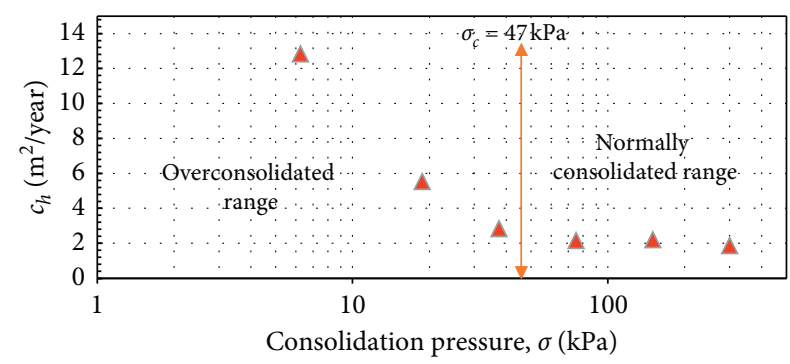

(a)

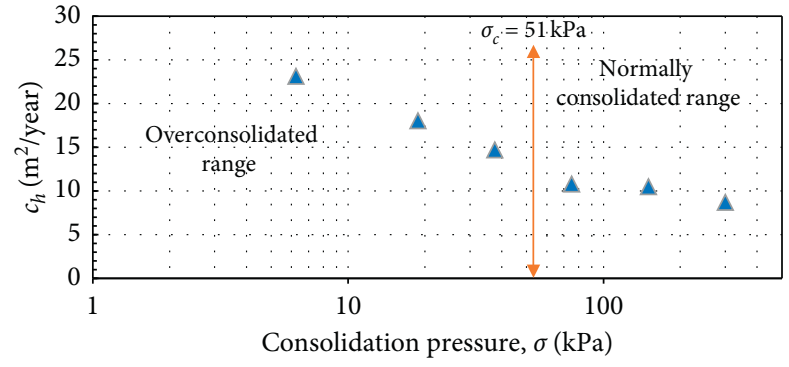

(b)

FIgURE 6: (a) The variation of $c_{h}$ with consolidation pressure (clay sample, depth: $2 \mathrm{~m}$-Site 2). (b) The variation of $c_{h}$ with consolidation pressure (sandy clay, depth: $6 \mathrm{~m}-$ Site 5).

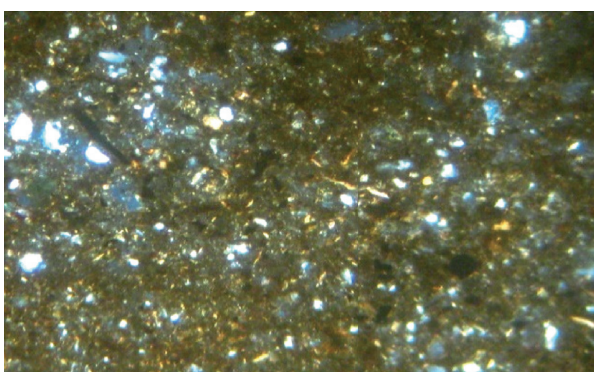

(a)

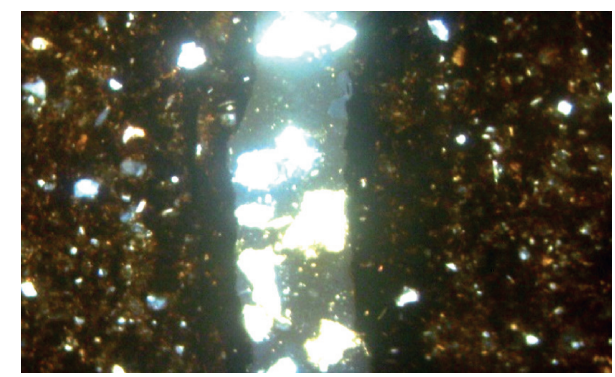

(b)

Figure 7: The anisotropy of soft clay at Site 6 (Ca Mau province) by microscopic observation: (a) vertical direction; (b) horizontal direction.

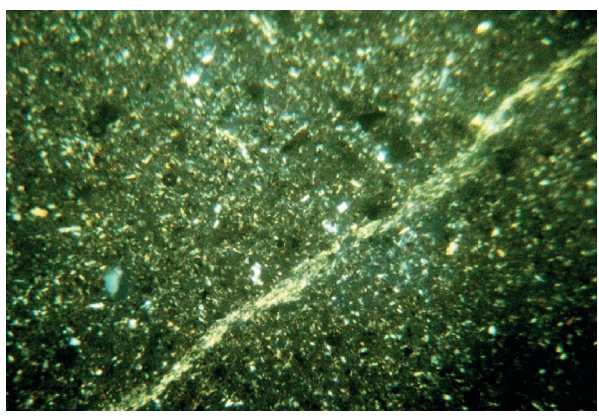

(a)

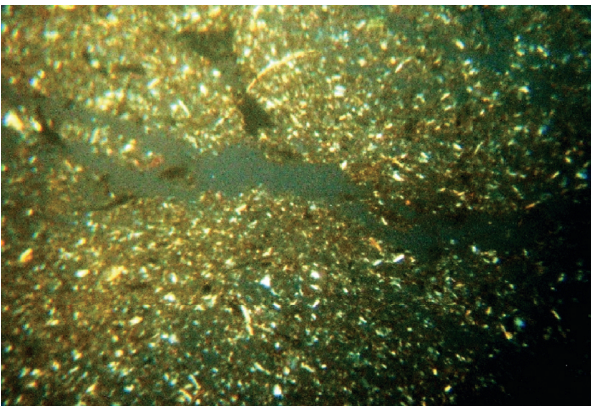

(b)

Figure 8: The anisotropy of soft clay at Site 4 (Soc Trang province) by microscopic observation: (a) vertical direction; (b) horizontal direction.

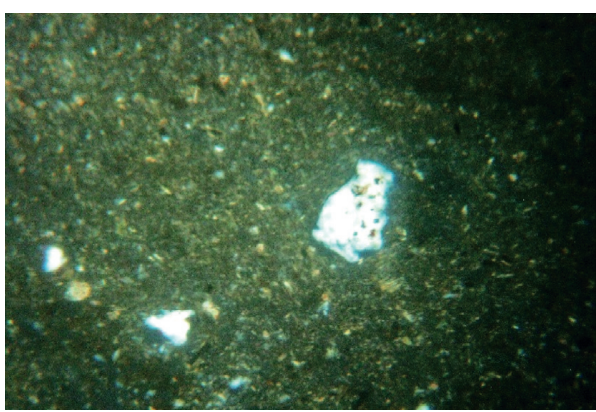

(a)

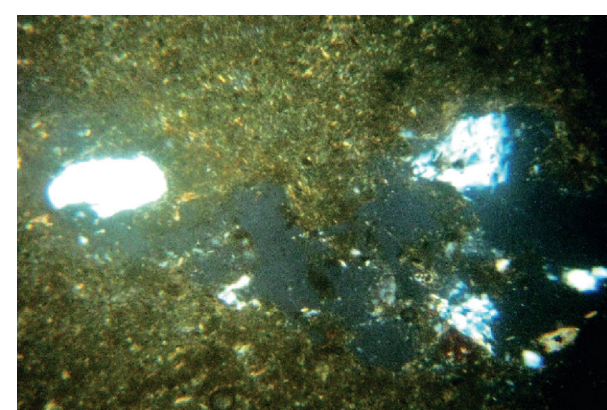

(b)

Figure 9: The anisotropy of soft clay at Site 7 (Kien Giang province) by microscopic observation: (a) vertical direction; (b) horizontal direction. 
As also shown in Table 2, the ratios of $c_{h} / c_{v}$ of soft sandy clay in normally consolidated state at the Site 1 and the Site 5 range from 1.35 to $3.12,3.13,5.91$ respectively. It may be believed that the soft sandy soil at the Site 5 is more anisotropic due to the interlacing with very thin sand or organic matter content.

It was also clearly seen that the $c_{h} / c_{v}$ ratio varies greatly depending on the structural characteristics or organic content in the soil (Figures 7 9).

\section{Conclusions}

In this paper, a study has been carried out to determine the horizontal coefficient of consolidation of Vietnam's soft soil. The results from the Rowe consolidation cell test, CRS-R, and CPTu dissipation test showed that the horizontal coefficient of consolidation of soft soil is commonly larger than the vertical coefficient of consolidation of soft soil. It was also found the ratios of $c_{h} / c_{v}$ are different in the types of soil and range from 1.35 10.59 and are affected by the organic matter and sedimental deposition environment. The result from Rowe cell and CRS-R agrees well with CRS-R and CPTu dissipation. It also showed that the ratio of $c_{h} / c_{v}$ depends on the consolidated pressure, so it was necessary to choose the $c_{h}$ value at consolidated pressure level for calculating the PVD spacing.

\section{Data Availability}

The data used to support the findings of this study are available from the corresponding author upon request.

\section{Conflicts of Interest}

The authors declare that there are no conflicts of interest regarding the publication of this paper.

\section{Acknowledgments}

We would like to thank Hanoi University of Mining and Geology for the provision of laboratory facilities used in this work and the support of Project (CT2020.04.MDA.02) of Ministry of Education and Training to complete this study.

\section{References}

[1] W.-Q. Feng, X. C. Zheng, J.-H. Yin, W.-B. Chen, and D.-Y. Tan, "Case study on long-term ground settlement of reclamation project on clay deposits in Nansha of China," Marine Georesources and Geotechnology, vol. 2019, pp. 1-16, 2019.

[2] W.-Q. Feng and J.-H. Yin, "A new simplified hypothesis B method for calculating consolidation settlements of double soil layers exhibiting creep," International Journal for $\mathrm{Nu}$ merical and Analytical Methods in Geomechanics, vol. 41, no. 6, pp. 899-917, 2017.

[3] F. Wei-Qiang and J.-H. Yin, "Development and verification of a new simplified method for calculating settlement of a thick soil layer with nonlinear compressibility and creep," International Journal of Geomechanics, vol. 20, no. 3, Article ID 04019184, 2019.
[4] H. M. Abuel-Naga, D. T. Bergado, and J. Gniel, "Design chart for prefabricated vertical drains improved ground," Geotextiles and Geomembranes, vol. 43, no. 6, pp. 537-546, 2015.

[5] R. A. Barron, "Consolidation of fine-grained soils by drain wells," Transactions of the American Society of Civil Engineers, vol. 113, no. 1, pp. 718-742, 1948.

[6] S. Hansbo, Soil Improvement by Preloading and Vertical Drain, Vol. 2011, Geotec Hanoi, Hanoi, Vietnam, 2011.

[7] S. Rabarijoely, "A new method for the estimation of hydraulic permeability, coefficient of consolidation, and soil fraction based on the dilatometer tests (DMT)," Studia Geotechnica et Mechanica, vol. 41, no. 4, pp. 212-222, 2019.

[8] R. Alzubaidi, "Effect rate of strain on in situ horizontal coefficient of consolidation from pressuremeter," Geotechnical and Geological Engineering, vol. 38, no. 2, pp. 1669-1674, 2019.

[9] G. Sridhar, G. R. Robinson, and K. Rajagopal, "Horizontal coefficient of consolidation from inward and outward flow tests," Proceedings of the Institution of Civil Engineers-Ground Improvement, vol. 171, no. 3, pp. 159-166, 2017.

[10] P. W. Rowe, "Measurement of the coefficient of consolidation of lacustrine clay," Géotechnique, vol. 9, no. 3, pp. 107-118, 1959.

[11] S. J. Trautwein, R. E. Olson, and R. L. Thomas, "Radial flow consolidation testing," in Proceedings of the 10th International Conference on Soil Mechanics and Foundation Engineering, Balkema, Stockholm, Sweden, pp. 811-814, 1981.

[12] D. Ganesalingam, N. Sivakugan, and W. Read, "Inflection point method to estimate ch from radial consolidation tests with peripheral drain," Geotechnical Testing Journal, vol. 19, no. 4, pp. 421-431, 1996.

[13] R. G. Robinson, "Analysis of radial consolidation test data using a log-log method," Geotechnical Testing Journal, vol. 36, no. 5, pp. 1-6, 2013.

[14] D. H. Shields and P. W. Rowe, "A radial drainage oedometer for laminated clays," Journal of Soil Mechanics and Foundation Division, vol. 19, no. 4, pp. 421-431, 1965.

[15] T. H. Seah and T. Juirnarongrit, "Constant rate of stain consolidation with radial drainage," Geotechnical Testing Journal, vol. 26, no. 4, pp. 1-6, 2003.

[16] R. G. Robinson, "Analysis of radial consolidation test data using a log-log method," Geotechnical Testing Journal, vol. 32, no. 2, pp. 119-125, 2009.

[17] G. Sridhar and R. Robinson, "Determination of radial coefficient of consolidation using log $\mathrm{t}$ method," International Journal of Geotechnical Engineering, vol. 5, no. 4, pp. 373-381, 2011.

[18] C. I. Teh and G. T. Houlsby, "An analytical study of the cone penetration test in clay," Géotechnique, vol. 41, no. 1, pp. 17-34, 1991.

[19] G. T. Houlsby and C. I. Teh, "Analysis of the piezocone in clay," in Proceedings of the International Symposium on Penetration Testing, ISOPT-1, vol. 2, Balkema, Orlando, FL, USA, pp. 777-783, 1988.

[20] L. Balachowski, "Soft soil overconsolidation and CPTu Dissipation test," Archives of Hydro-Engineering and Environmental Mechanics, vol. 53, no. 2, pp. 155-180, 2006.

[21] K. Suzuki and H. Takeuchi, "Performance of band shaped vertical drain for soft Hai Phong clay," Soils and Foundations, vol. 48, no. 4, pp. 577-585, 2008.

[22] K. Suzuki and N. Cong Oanh, "Apparent value of ch determined from field behavior of two soft clay deposits in Southern Vietnam," in Proceedings of the International 
Conference GEOTECH HANOI 2011-Geotechnics for Sustainable Development, Hanoi, Vietnam, October 2010.

[23] S.-A. Tan and S.-H. Chew, "Comparison of the hyperbolic and Asaoka observational method of monitoring consolidation with vertical drains," Soils and Foundations, vol. 36, no. 3, pp. 31-42, 1996.

[24] J. Chu, M. W. Bo, M. F. Chang, and V. Choa, "Consolidation and permeability properties of Singapore marine clay," Journal of Geotechnical and Geoenvironmental Engineering, vol. 128, no. 9, pp. 724-732, 2002.

[25] K. H. Head, Manual of Soil Laboratory Testing, Vol. 3, Pentech Press, London, UK, 2006.

[26] P. W. Mayne, "Stress-strain-strength-flow parameters from enhanced in-situ tests," in Proceedings, International Conference on In-Situ Measurement of Soil Properties \& Case Histories [In-Situ 2001], Bali, Indonesia, May 2001.

[27] M. M. Baligh and J. N. Levadoux, "Consolidation after undrained piezocone penetration. II: interpretation," Journal of Geotechnical Engineering, vol. 112, no. 7, pp. 727-745, 1986.

[28] T. H. Seah, "Horizontal coefficient of consolidation of soft Bangkok clay," Geotechnical Testing Journal, vol. 27, no. 5, 2004.

[29] N. Gofar, "Determination of coefficient of rate of horizontal consolidation of peat soil," Laporan Projek Penyelidikan Fundamental, 2006. 